\title{
EMPLOYMENT AND LABOUR MARKET IMPACT OF COVID-19 CRISIS - PART 1 - ANALYSIS IN POLAND
}

doi: $10.2478 /$ czoto-2021-0012

Date of submission of the article to the Editor: 4/01/2021

Date of acceptance of the article by the Editor: 1/04/2021

\author{
Joanna Rosak-Szyrocka ${ }^{1}$ - orcid id: 0000-0002-5548-6787 \\ Ali Abdulhassan Abbas ${ }^{2}$ - orcid id: 0000-0001-6860-2583 \\ Humair Akhtar ${ }^{3}$ - orcid id: 0000-0003-1127-427X \\ Craig Refugio ${ }^{4}$ - orcid id: 0000-0003-1374-6103 \\ ${ }^{1}$ Czestochowa University of Technology, Poland \\ ¿University of Kerbala, Iraq \\ 3University of Haripur, Pakistan \\ ${ }^{4}$ Negros Oriental State University, Philippines
}

\begin{abstract}
The world is changing really fast. This speed is caused by urbanization, technological development and the increasing demand for energy. Such changes have a direct impact on enterprises which function in the world of VUCA (volatility, uncertainty, complexity and ambiguity) with numerous surprises in the form of "black swans", i.e. rare and unpredictable events. The modern history has not seen such a lockdown as the one caused by the coronavirus. Hairdressers, cosmeticians, restaurants, transportation and tourism are particularly affected by the negative effects of the pandemic. But while some lose, others profit: growth can be observed in the areas of e-commerce, courier shipping and parcel lockers. The article analyzes the labor market in covid times. The image of enterprises and employees of the future was discussed. The paper is an introduction part of an international research conducted as part of cooperation between Universities from Poland, Pakistan, Iraq and the Philippines.
\end{abstract}

Key words: labour market, covid-19, employee

\section{INTRODUCTION}

The COVID-19 crisis hit Europe in the frst quarter of 2020. In March 2020, an epidemic emergency was announced in Poland, followed by an epidemic in connection with the spread of an infectious disease caused by the SARS-CoV-2 virus, known as COVID19 , which caused the collapse of the Polish economy and, consequently, had a strong impact on the labor market. The COVID-19 pandemic is having a dramatic economic impact in most countries (Dias Costa et al., 2020). According to (Dingel and Neiman, 2020 , the share of jobs that can be done at home exceeds $40 \%$ in Sweden and the UK, while the proportion decreases in the cases of France $(38 \%)$, Italy $(35 \%)$ or Spain (32\%). 
Globally, there have been 83715617 confirmed cases of COVID-19, including 1835901 deaths, reported to WHO. As an example from Jan 3, 4 January 2021:

- In Poland, there have been 1318562 confirmed cases of COVID-19 with 29119 deaths,

- In Iraq, there have been 597774 confirmed cases of COVID-19 with 12834 deaths.

- In Pakistan, there have been 486634 confirmed cases of COVID-19 with 10311 deaths.

- In Philippines, there have been 477807 confirmed cases of COVID-19 with 9257 deaths.

After the outbreak of the pandemic in Poland, the number of available jobs shrank significantly, and the demand for labor clearly decreased. In the first quarter of 2020, 119.9 thousand jobs were liquidated. jobs, and about a quarter of jobs have been lost due to the epidemic, which largely affected the private sector. In the second quarter of 2020, 93.6 thousand jobs were liquidated. jobs. It was $21.9 \%$ less than in the first quarter of 2020. However, the scale of job losses increased due to the spread of COVID-19. While in the first quarter such a relationship referred to approximately $1 / 4$ of the liquidated jobs, in the second quarter to $1 / 3$. According to a study conducted by Grant Thornton and Element, in May 2020, employers published 195.1 thousand jobs on the 50 largest recruitment portals in Poland. new job offers. This is a huge drop compared to May 2019 - the number of new job offers shrank by 138.8 thousand. This means that the recruitment activity of employers decreased by $41.6 \%$. In April 2020 , the decrease in the number of new job offers was even stronger and amounted to $50.7 \%$. annually. The coronavirus pandemic is causing economies around the world to continue to suffer huge losses. Due to the present situation, enterprises are forced to limit their activities, and therefore they make mass layoffs and stop hiring new ones. According to the Pracuj.pl report, in March 2020 the labor market in Poland was relatively stable, but in April the decline in demand for employees was significant.

\section{LABOR MARKETS SITUATION ANALYSIS IN THE FACE OF THE PANDEMIC}

As noticed researchers carried out through authors (Fana et al., 2020; Andersen et al., 2020; Béland et al., 2020; Blundell et al., 2020; Caselli et al., 2020; del Rio-Chanona et al., 2020; Pouliakas and Branka, 2020) the impact of the crisis is being clearly asymmetric, with the most vulnerable countries and segments of the workforce being hardest hit by the pandemic. The coronavirus has a strong impact especially on the local labor markets of large cities. The differences between them are very clear (Figure 1). Before the pandemic, the great difficulties in attracting and retaining valuable employees in the organization were emphasized. As a consequence, organizations sought various methods not only in the area of active recruitment of employees, but also creating attractive employment conditions for them and offering various types of benefits. The economic crisis caused by covid-19 is not only the cause of a reduction in the number of published job offers, but also the content of job advertisements changes, which are not as attractive as before in terms of benefits, e.g. sports cards or a medical package. The Grant Thornton report shows that in May 2020, employers withdrew most of the additional benefits offered to future employees, currently only 30 percent. Companies offer applicants a private medical care package and only 27 percent. offers surcharges for the sports card. Reducing the attractiveness of job advertisements is caused by employers seeking savings, so they are forced to "cut costs". 


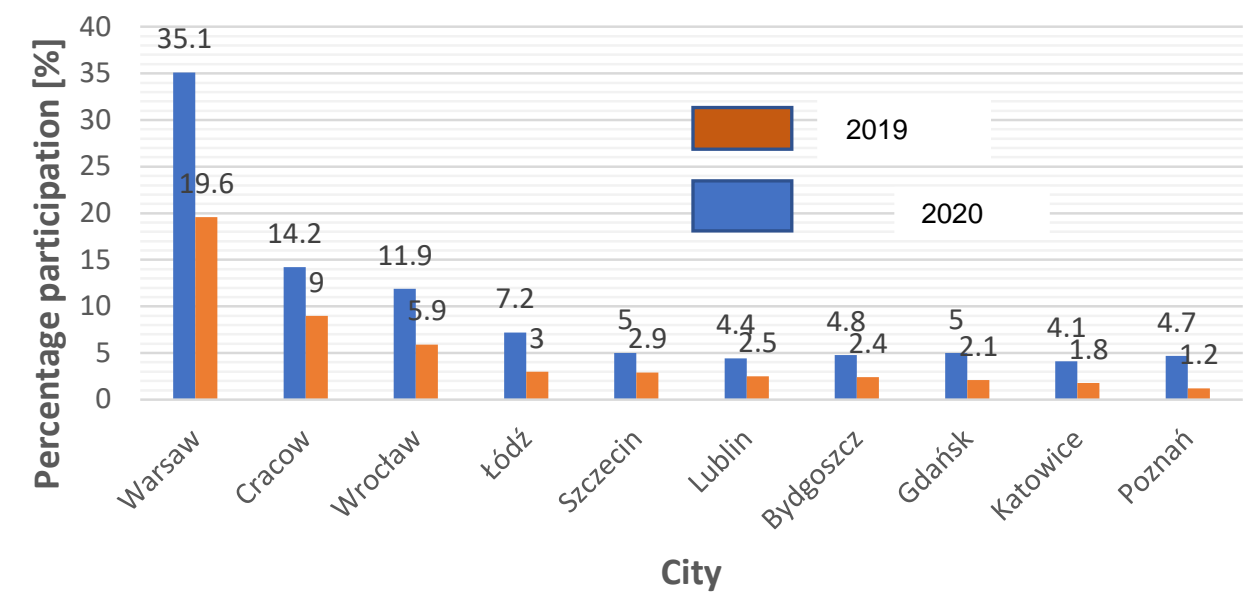

Fig 1. The number of new job offers in the 10 largest cities in Poland in May 2020 and the change compared to May 2019

Source:https://grantthornton.pl/wp-content/uploads/2020/06/Rynek-pracy-w-czasie-koronawirusa-w-majuRAPORT.pdf date: 28.12 .2020

Currently, the main incentive that employers tempt candidates is training that is conducted on the company's premises or in the form of webinars (Figure 2).

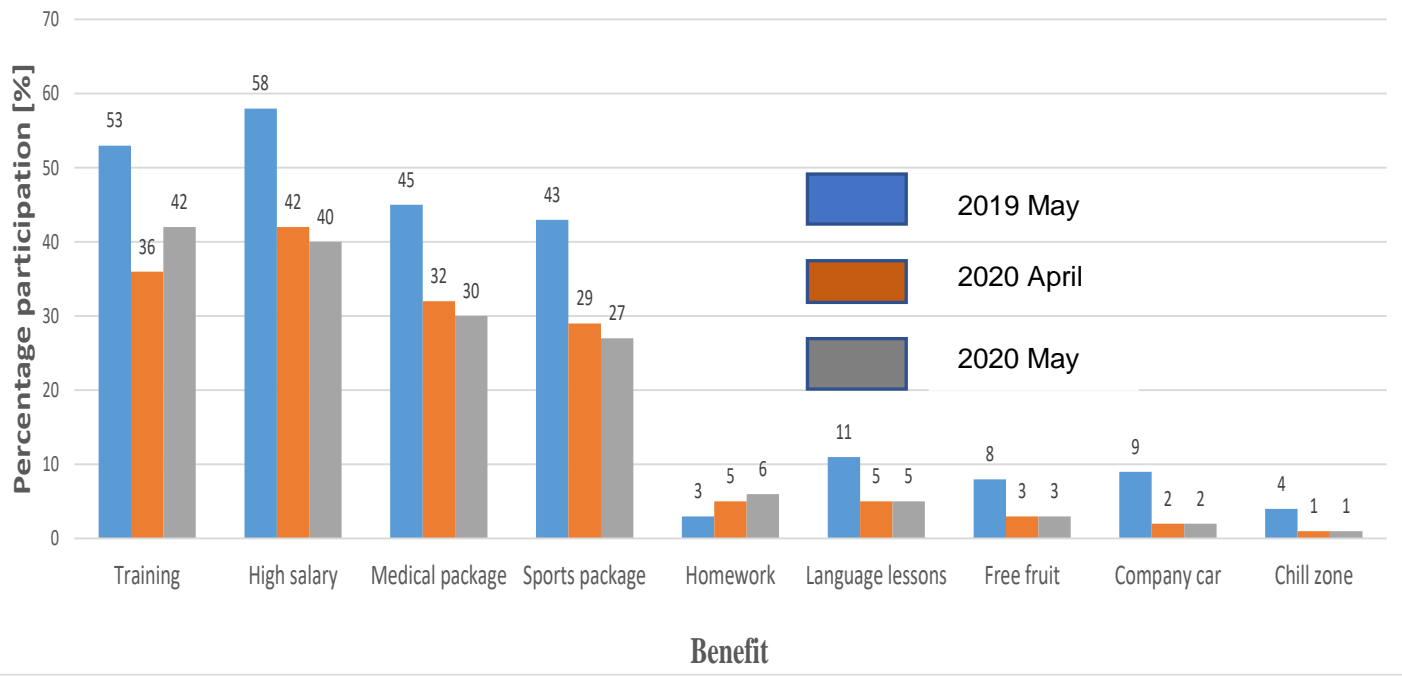

Fig 2. Percentage of job offers with specific incentives

Source: https://grantthornton.pl/wp-content/uploads/2020/06/Rynek-pracy-w-czasie-koronawirusa-wmaju-RAPORT.pdf date: 28.12.2020

The number of job offers in May 2020 also changed compared to May 2019 (Table 1). As can be seen from Table 1, the greatest decline in terms of job offers can be seen among administration and human resources employees, which decreased by as much as $72 \%$. The lowest drop in demand concerns specialists in the area of finance, but it is interesting that there are even more offers for chief accountants than before the crisis and amounts to $+21 \%$. 
Table 1

The number of job offers in May 2020 compared to May 2019

\begin{tabular}{|c|c|}
\hline Job offers & $\begin{array}{r}\text { Percentage of job offer decline in May } \\
\mathbf{2 0 2 0} \text { compared to May 2019 }\end{array}$ \\
\hline Secretarial employee & $-72 \%$ \\
\hline HR Business Partner & $-65 \%$ \\
\hline Warehouseman & $-55 \%$ \\
\hline Programmer & $-54 \%$ \\
\hline Shop assistance & $-52 \%$ \\
\hline Security guard & $-51 \%$ \\
\hline Driver & $-50 \%$ \\
\hline Marketing specialist & $-41 \%$ \\
\hline Financial analyst & -33 \\
\hline Chief Accountant & $+21 \%$ \\
\hline
\end{tabular}

Source: https://grantthornton.pl/wp-content/uploads/2020/06/Rynek-pracy-w-czasie-koronawirusa-wmaju-RAPORT.pdf date: 28.12 .2020

\section{EMPLOYEE IN POLAND IN THE FACE OF COVID-19}

In the first months after the outbreak of the pandemic in Poland, the requirements of employers towards employees dropped sharply, and moreover, companies began to look for employees for simple jobs that did not require additional skills, e.g. for a grocery store or a courier company, because they experienced an increase in demand or were affected by the outflow of employees from Ukraine (Figure 3). Currently, the situation is returning to normal and entrepreneurs are again increasing the requirements for employees. The most common requirement that employers place on employees is professional experience (65\%) and appropriate education (40\%). It can also be seen that the requirement of availability has increased significantly (from 17\% to 29\%), while the requirement of knowing a foreign language has decreased.

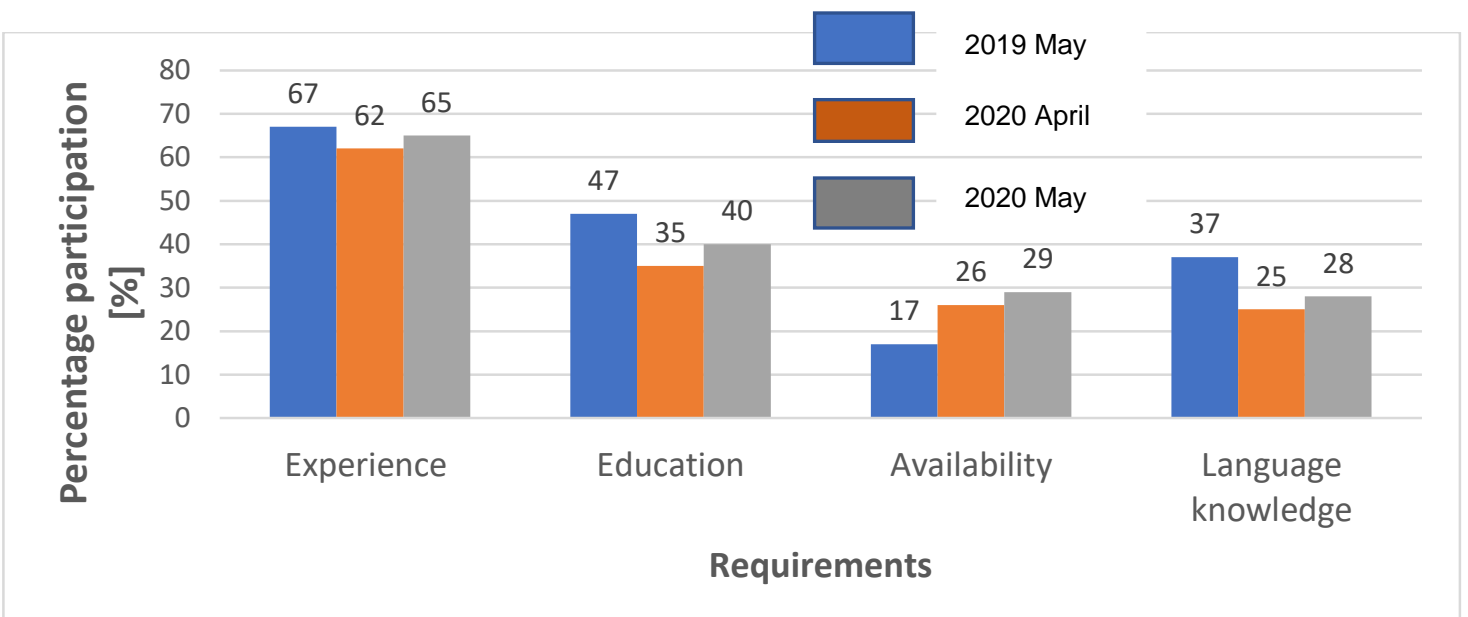

Fig. 3. Percentage of job offers with specific requirements for candidates

Source: $\quad$ https://grantthornton.pl/wp-content/uploads/2020/06/Rynek-pracy-w-czasie-koronawirusa-wmaju-RAPORT.pdf date: 28.12 .2020 
There are key trends in the finding of employees in Poland in the labor market in the face of the coronavirus and the changes introduced by covid-19 in their working lives (Table 2).

Table 2

Trends in finding employees in Poland in the labor market in the face of the coronavirus and changes introduced by covid in their working life.

\begin{tabular}{|c|c|}
\hline $\begin{array}{l}\text { Trends in finding employees in Poland in } \\
\text { the labor market in the face of the } \\
\text { coronavirus }\end{array}$ & Characteristic \\
\hline Uncertainty of the professional future & $\begin{array}{c}\text { Over } 40 \% \text { of respondents are afraid of losing } \\
\text { their job due to the coronavirus epidemic, } \\
\text { and as much as } 60 \% \text { - a reduction in salary } \\
\text { or a change in employment rules. }\end{array}$ \\
\hline Openness to new career paths & $\begin{array}{l}77 \% \text { of the employed respondents are ready } \\
\text { to accept a new job offer. } \\
64 \% \text { of jobseekers are ready to retrain in the } \\
\text { current situation. }\end{array}$ \\
\hline $\begin{array}{l}\text { The need for work safety and } \\
\text { stabilization }\end{array}$ & $\begin{array}{l}58 \% \text { would accept a job offer if it would } \\
\text { guarantee stable and safe employment. }\end{array}$ \\
\hline $\begin{array}{c}\text { Working outside the office is still } \\
\text { attractive }\end{array}$ & $\begin{array}{l}9 \text { out of } 10 \text { respondents want to be able to } \\
\text { work remotely at least partially after the } \\
\text { coronavirus restrictions are lifted, and most } \\
\text { respondents expect the importance of } \\
\text { remote work to increase in the future. }\end{array}$ \\
\hline Remote work as a challenge for parents & $\begin{array}{c}79 \% \text { of the respondents bringing up children } \\
\text { believe that remote work is a greater } \\
\text { challenge for them than for childless people. } \\
57 \% \text { find it difficult to separate private and } \\
\text { work time. }\end{array}$ \\
\hline Readiness for remote recruitment & $\begin{array}{c}49 \% \text { of respondents are more likely to apply } \\
\text { for recruitments conducted fully remotely, } \\
\text { and } 71 \% \text { - positively assess the possibility of } \\
\text { video interviews. }\end{array}$ \\
\hline
\end{tabular}

Source: own study basis on: https://prowly-uploads.s3.eu-west-

1.amazonaws.com/uploads/landing_page_image/image/266143/f8f1b4f13d3af3f28575dea557d6ac27.pd f date: 28.12 .2020

It is worth emphasizing that in the era of a pandemic, employees are aware of the difficult situation in which covid-19 has introduced the economy and the labor market. The pandemic meant that for many employees remote work has become not so much a benefit, but an opportunity to reduce the risk of infection. In addition, the conditions of remote work have changed significantly. Figure 4 shows the share of employed people who, due to the epidemic situation, worked remotely according to the Polish 
Classification of Activities (PKD) in the first and second quarter of 2020. On the basis of the presented Figure 4, it can be concluded that the largest increase in remote work is currently shown in the areas of information and communication, professional, scientific and technical activities. The Pracuj.pl report shows that as many as $75 \%$ of respondents believe that finding a job will be more difficult than before, while only $11 \%$ of respondents working remotely in connection with covid-19 declare that they would not want to work remotely after lifting the restrictions. Mixed models are the most popular, which means that $40 \%$ of respondents would like to be able to come to the office at least once a week, and $39 \%$ of respondents would like to be able to work outside the office only on selected days of the month. More than a half, i.e. $64 \%$ of the surveyed employees working remotely believe that their employers have organized remote work well. Covid-19 will accelerate the growing importance of remote work in the labor market.

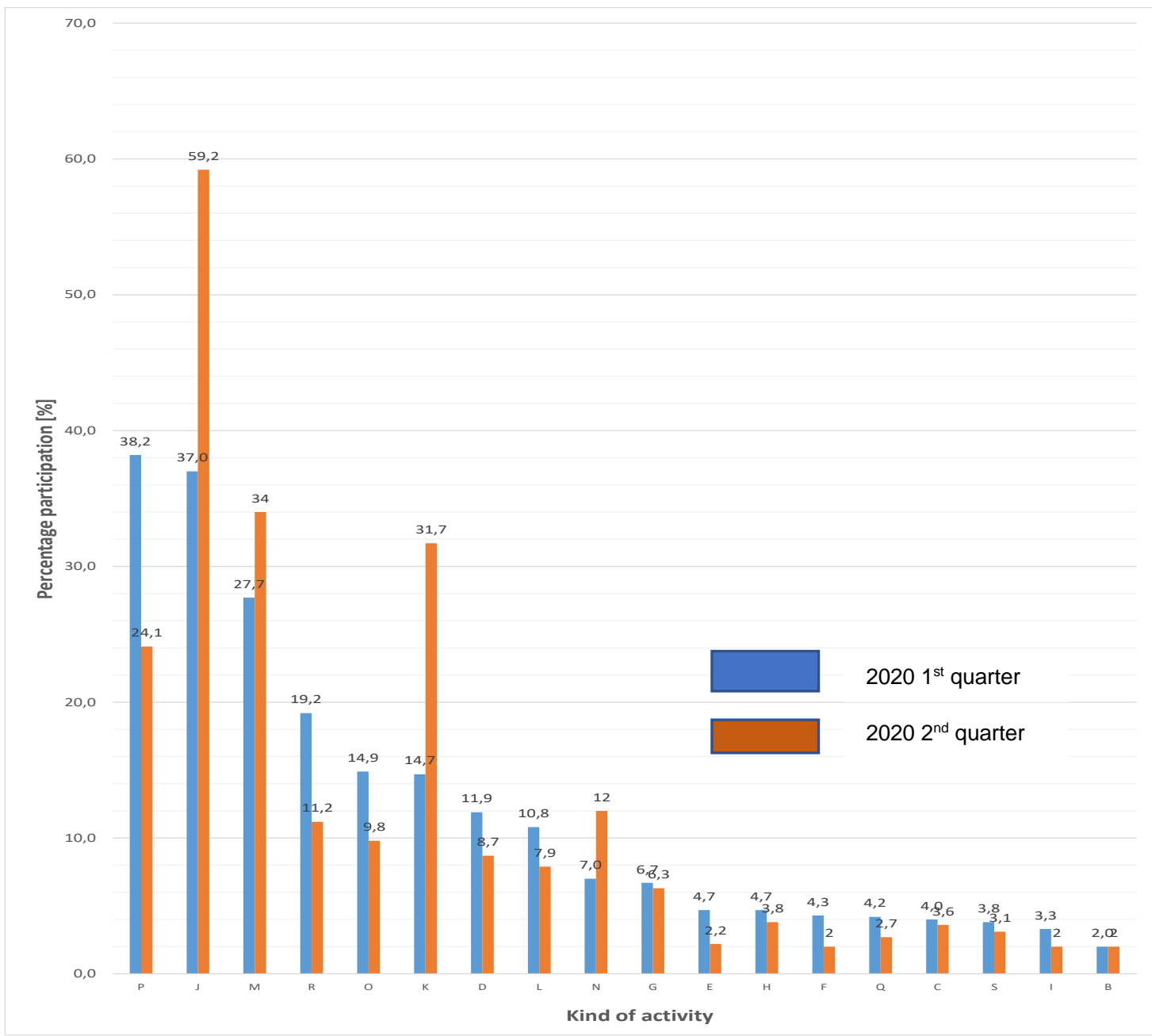

Fig. 4. The share of employed people who, due to the epidemic situation, worked remotely according to the Polish Classification of Activities (PKD) in the first and second quarter of 2020.

Source: Central Statistical Office: The impact of the COVID-19 epidemic on selected elements on 10/09/2020 of the labor market in Poland in Q1 and Q2 2020

\section{Legend:}

Education $(\mathrm{P})$, Information and Communication $(\mathrm{Y})$, Professional activities, scientific and technical (M), Arts, entertainment and recreation (R), Public administration and defense; compulsory social security (O) 
Financial and Insurance Activities (K), Generation and supply of electricity, gas, steam, hot water and air for air conditioning equipment (D), Real estate activities (L), Business administration and support, activities $(\mathrm{N})$, Wholesale and retail trade; repair of motor vehicles, including motorcycles (G), "Water supply; sewage management, and waste and remediation activities $(E)$, Transport and warehouse management $(H)$, Construction $(F)$, Healthcare and Social Work (Q), Manufacturing (C), Other service activities (S), Accommodation Activities and catering services (I), Mining and Quarrying (B).

There are many advantages of remote work:

- greater flexibility of the employee,

- possibility of adjusting to various life circumstances,

- adaptation to individual needs in terms of work space,

- the possibility of reconciling work and personal life (including family life),

- spending more time with loved ones,

- greater involvement of the employee in the work performed by him (e.g. due to the possibility of better concentration on tasks, work in peace and quiet),

- greater motivation to work,

- faster and more efficient performance of duties,

- greater efficiency and productivity,

- feeling more satisfied with work and life,

- reducing the stress level.

As noticed authors (Almarzooqi And Alaamer, 2020) working from home equipped workers with a quiet environment where they are shielded from continuous distractions by colleagues, especially in a shared office space. Moreover workers explained that they enjoyed the freedom to schedule their time to suit their performance patterns rather than tailor their working day on the rhythm of the surrounding environment.

\section{CONCLUSIONS}

The nature of the economic shock associated with COVID-19 is highly unusual. Analysis of labor market and employee data in covid times shows that the COVID crisis is so deep that it will not only radically affect labour markets in the short and medium run, but it can also change substantially the way the work is organized (Caselli et al., 2020).

Companies are currently striving for the so-called inclusive work organization - that is, one that will be able to use the potential and create equal opportunities, regardless of whether someone will work more in the office, at home or in a hybrid. Opinions about the labor market in Poland are very divided. Much is said about the definitive end of the employee market. It is certain that we are experiencing changes and we are still waiting for more, while the competence of the future, i.e. "learning agility" - becomes a competence required today, because abilities such as adaptability or the speed of learning are key to find ourselves in a very volatile and still unstable the labor market. Remote work can therefore be one of the benefits for the employee, as well as contribute to generating savings for the employer and reducing the degradation of the natural environment. Employees of the future will have to be flexible and ready for lifelong learning.

Research carried out by Bergman Engineering shows that currently as many as 9 out of 10 employers are looking for specialists who can think critically, and in recent months the demand for specialists who could work on a project basis, i.e. on contracting, instead of employment contract. In the long-term perspective, it seems that the interest of employers in software, systems, and equipment enabling more flexible operations of entire teams, as well as many employers reach for solutions that can be implemented the fastest, allowing to temporarily manage the situation. In the future, companies will 
invest more in remote work tools, because they will appreciate its advantages, but also see savings related to remote work. The ability to work remotely, good work organization and soft skills will also become even more important advantages of employees. It is predicted that in the future, the ability to work remotely effectively will be an even more important asset for an employee than at present. Research carried out on behalf of Siemens and the Ministry of Entrepreneurship and Technology shows that engineering competences of the present day are a combination of hard technical qualifications with their "soft" counterparts, and the key to success is the ability to work in a team combined with effective communication of processes.

\section{REFERENCES}

Almarzooqi, B., Ameen A., 2020. Worker Perceptions on Working from Home during COVID-19 Pandemic Empirical Evidence from Bahrain, DOI: 10.2139/ssrn.3643890

Andersen, A. L., Hansen, E. T., Johannesen, N., \& Sheridan, A., 2020. Pandemic, shutdown and consumer spending: lessons from scandinavian policy responses to COVID-19, Papers arXiv, May 2005.

Béland, L.-P., Brodeur, A., \& Wright, T., 2020. The short-term economic consequences of COVID-19: exposure to disease, remote work and government response, IZA Discussion Paper Series (13159).

Blundell, J., Machin, S., (2020). Self-employment in the Covid-19 crisis. A CEP Covid19 analysis, Paper No. 003, Centre for Economic Performance, London School of Economics and Political Science.

Caselli, M., Fracasso, A., Traverso, S., 2020. Mitigation of risks of Covid-19 contagion and robotisation: evidence from Italy. Covid Economics, Vetted and Real-Time Papers, The Centre for Economic Policy Research.

Central Statistical Office, The impact of the COVID-19 epidemic on selected elements on 10/09/2020 of the labor market in Poland in Q1 and Q2 2020.

del Rio-Chanona, R. M., Mealy, P., Pichler, A., Lafond, F., Farmer, J. D., 2020. Supply and demand shocks in the COVID-19 pandemic: An industry and occupation perspective. Covid Economics, Centre for Economic Policy Research., 6, 65-103.

Dias Costa M., Joyce R., Postel-Vinay F., Xu X., 2020. The Challenges for Labour Market Policy during the COVID-19 Pandemic, 41, 2, 371-382.

Dingel, J. I., \& Neiman, B., 2020. How many jobs can be done at home? White Paper, Becker Friedman Institute.

Fana M., Pérez S. T., Fernández-Macías E., 2020. Employment impact of Covid-19 crisis, from short term efects to long terms prospects, Journal of Industrial and Business Economics, 47, 391-410.

https://covid19.who.int/ date: 4.01.2021.

https://grantthornton.pl/wp-content/uploads/2020/06/Rynek-pracy-w-czasiekoronawirusa-w-maju-RAPORT.pdf date: 28.12.2020

https://prowly-uploads.s3.eu-west1.amazonaws.com/uploads/landing_page_image/image/266143/f8f1b4f13d3af3f28 575dea557d6ac27.pdf date: 28.12.2020.

Pouliakas, K., \& Branka, J., 2020. EU jobs at highest risk of COVID-19 social distancing: is the pandemic exacerbating the labour market divide? Cedefop - Working Paper Series. 